\title{
ADENOCARCINOMA OF THE ESOPHAGOGASTRIC JUNCTION: relationship between clinicopathological data and p53, cyclin D1 and Bcl-2 immunoexpressions
}

\author{
Dárcio Matenhauer LEHRBACH ${ }^{1}$, Ivan CECCONELL 0 ${ }^{1}$, Ulysses RIBEIRO Jr. ${ }^{1}$, \\ Vera Luiza CAPELOZZI ${ }^{2}$, Alexandre Muxfeldt Ab'SABER $^{2}$ and Venâncio Avancini Ferreira ALVES ${ }^{2}$
}

\begin{abstract}
Context - Esophagogastric junction adenocarcinoma has an aggressive behavior, and TNM (UICC) staging is not always accurate enough to categorize patient's outcome. Objectives - To evaluated p53, cyclin D1 and Bcl-2 immunoexpressions in esophagogastric junction adenocarcinoma patients, without Barrett's esophagus, and to compared to clinicopathological characteristics and survival rate. Methods - Tissue sections from 75 esophagogastric junction adenocarcinomas resected from 1991 to 2003 were analyzed by immunohistochemistry for p53, cyclin D1 and Bcl-2 using streptavidin-biotin-peroxidase method. The mean follow-up time was 60 months SD $=61.5$ (varying from 4 to 273 months). Results - Fifty (66.7\%) of the tumors were intestinal type and $25(33.3 \%)$ were diffuse. Vascular, lymph node and perineural infiltration were verified in $16 \%, 80 \%$ and $68 \%$ of the patients, respectively. The patients were distributed according to the TNM staging in IA in 4 (5.3\%), IB in $10(13.3 \%)$, II in $15(20 \%)$, IIA in $15(20 \%)$, IIIB in $15(20 \%)$ and IV in $16(21.3 \%)$. Immunohistochemical analysis was positive for p53, cyclin D1 and bcl-2 in $68 \%, 18.7 \%$ and $100 \%$, respectively. There was no association between immunoexpression and vascular and/or perineural invasions, clinicopathological characteristics and patients' survival rate. Conclusion - In this selected population, there was no association between the immunomarkers, p53, cyclin D1 and bcl-2 and clinicopathological data and/or overall survival.
\end{abstract}

HEADINGS - Esophagogastric junction. Stomach neoplasms. Esophageal neoplasms. Adenocarcinoma. Tumor suppressor protein p53. Cyclin D1. Proto-oncogene proteins c-bcl-2.

\section{INTRODUCTION}

During the last decades, it was observed an increased prevalence of esophagogastric junction (EGJ) adenocarcinoma in the Western developed countries. In the fifties, the adenocarcinoma represented less than $5 \%$ of the esophageal tumors in the United States and Europe $^{(4)}$. In the eighties and nineties, this figures climb up to approximately $50 \%{ }^{(3,15)}$. In Brazil, esophageal cancer is the 10th more common neoplasia, with high mortality rate due to the delayed diagnosis. It is estimated the occurrence of 10,580 new cases of this cancer for this year ${ }^{(16)}$. TNM (UICC) staging system is not always accurate enough to categorize the patient status adequately. Occasionally, patients with similar clinical staging may have different outcome, and others classified differently may present comparable results. Molecular and genetic biology research can perhaps clarify these facts.
Immunohistochemistry method can be used to evaluate some of the tumor markers, including p53, cyclin-D1 and Bcl-2. However, the published results in the evaluation of these markers in patients with EGJ adenocarcinoma still remain controversial.

p53 is a tumor-suppressor gene located in the chromosome $17 \mathrm{p} 13$, that encodes a phosphoprotein with important role in the maintenance of the cellular integrity. It suppresses the oncogenic transformation by the interruption of the cellular cycle in the G1 phase, providing time so that the damage either can be repaired or apoptosis can be induced ${ }^{(8,9,26,27,28)}$. p53 gene mutations occur in approximately $50 \%$ of all human tumors and can be detected by immunohistochemistry when this protein is overexpressed in the nucleus of the cells.

The cyclin D1 is a proto-oncogene located in the chromosome 11q13, which form a complex with kinases dependents on cyclins (CDK4/6), leading

This manuscript was presented at the $7^{\text {th }}$ International Gastric Cancer Congress of the International Gastric Cancer Association, May 10-12, 2007, São Paulo, SP, Brazil. Departments of ${ }^{1}$ Gastroenterology and ${ }^{2}$ Pathology, University of São Paulo School of Medicine, São Paulo, SP, Brazil.

Address: Dárcio Matenhauer Lehrbach - Rua Francisco Pereira Coutinho, 234, apt. 124-B - Vila Rafael de Oliveira - 13201-100 - Jundiaí, SP, Brazil. E-mail: darcioml@terra.com.br 
to the phosphorilation of the retinoblastoma protein $(\mathrm{Rb})$ and restarting the cellular proliferation by releasing the E2F factor of transcription that, in this free condition, activate genes that are essential for the entrance of the cell in S (synthesis) phase. The genes p27, p21 and p16 act inhibiting the activation of cyclin complex D1-CDK4/6. The overexpression of cyclin D1 promotes the early entrance of the cell in S phase, and its inhibition interrupts the cycle right after this phase ${ }^{(28)}$

The bcl-2 gene of the chromosome 18q21 inhibits apoptosis and is normally expressed in the proliferating epithelial zones. In the normal esophageal epithelium, a weak bcl-2 expression is found in the basal zone, while the immunoexpression is more intense in $76 \%$ to $100 \%$ of the patients with Barrett's esophagus, in $25 \%$ of the patients with high-grade dysplasia, and in $20 \%$ of the patients with adenocarcinoma ${ }^{(22,28,37)}$.

Thus, the objective of this investigation was to evaluate patients with EGJ adenocarcinoma, without Barrett's esophagus, for immunoexpression of p53, cyclin D1 and $\mathrm{Bcl}-2$. Markers immunoexpression rates were associated to clinicopathological data and postoperative overall survival.

\section{METHODS}

This study was approved by the Ethics Committee of the "Hospital das Clínicas", University of São Paulo School of Medicine, São Paulo, SP, Brazil. Hospital records from 1993 to 2003 of 75 patients with EGJ adenocarcinoma who underwent surgical resection at the Digestive Surgery of the Department of Gastroenterology of the University of São Paulo were reviewed. The mean age was $64.2 \pm 14$ years (varied from 36 to 89 years-old) and $67(89.3 \%$ ) patients were men. Histological sections representing tumors of the 75 surgical resected patients were selected for this study. Preceding radio or chemotherapy, previous esophageal operation, other histological tumors than adenocarcinoma, presence of Barrett's esophagus, achalasia or megaesophagus, or history of corrosive agent ingestion cases were excluded from the study.

Histological slides were reviewed to confirm the histopathological diagnosis of EGJ adenocarcinoma (type II tumors of Siewert's classification) without Barrett's esophagus by H-E. Histological findings were graded according to the Laurén's classification, and the pTNM staging was reviewed ${ }^{(43)}$. Vascular, lymph node and perineural infiltration were also evaluated. Corresponding formalin-fixed paraffin-embedded tissue blocks were sectioned for immunohistochemical analysis. Five to six unstained $4 \mathrm{~mm}$ blank histological sections were cut from each designated block. One blank was used for p53 immunostaining (suppressor pathway) (p53 - NCL p53-DO7, Novocastra, Newcastle, UK), other blank for cyclin D1 (cyclin D1, DCS-6, DAKO) ${ }^{(29)}$, and other for Bcl-2 (Bcl-2 $-124 \mathrm{DAKO})^{(34)}$ using the streptavidin-biotin-peroxidase complex method. The microwave oven heating technique for antigen retrieval and immunodetection method has been previously described ${ }^{(36,39)}$. Briefly, immunodetection involved the use of $4 \mathrm{~mm}$ thick formalin-fixed paraffin-embedded tissues, treated with $4 \%$ hydrogen peroxidase $\left(\mathrm{H}_{2} \mathrm{O}_{2}\right)$ in methanol for 35 minutes to eliminate endogenous peroxidase activity. The sections were placed in the microwave oven for 10 minutes for antigen retrieval, rinsed in phosphatebuffered saline (PBS) and incubated with 10\% normal horse serum to block nonspecific binding. Upon removal of the serum, the primary monoclonal antibody was applied at room temperature. Following further washing with PBS, sections were incubated with biotinylated antimouse immunoglobulin for 30 minutes. After washing twice with PBS, the sections were treated with Vectastain Elite horseradish peroxidase complex (Vector Laboratory, Burlingame, CA) for 30 minutes. Following another rinse with PBS, the sections were incubated with diaminobenzidine $0.05 \%$ and $0.04 \% \mathrm{H}_{2} \mathrm{O}_{2}$ for 20 minutes. After a final wash with distilled water, the sections were counterstained with Harris Alum Hematoxylin, dehydrated through graded alcohols to xylene, and cover-slipped. Sections of gastric adenocarcinoma and primary antibody replaced by PBS were used as positive and negative controls, respectively. Specific nuclear immunoreactivity for $\mathrm{p} 53$ and cyclin D1 proteins was scored semiquantitatively on a graded scale of 0 through 4 for both intensity and distribution by three investigators in a blinded analysis. p53 was classified solely as positive immunostaining when greater than $2^{(40)} \mathrm{Bcl}-2$ immunoexpression was evaluated by cytoplasmic staining, and was also scored semiquantitatively on a graded scale of 0 through 4 for both intensity and distribution.

Clinicopathological characteristics of the tumors and immunoexpressions were compared using Mann-Whitney test, Fishers' exact probability test and Pearson chi-square test for qualitative data, with two tailed $P$ value at the 5\% level considered significant. Kaplan-Meier method was used to calculate the survival curves, while log-rank test was utilized to compare the curves. For statistical proposals the parameters were classified in: $\mathrm{pT}$ ( $\mathrm{T} 1$ versus $\mathrm{T} 2$ and $\mathrm{T} 3$ ), $\mathrm{pN}(\mathrm{N} 0$ versus $\mathrm{N}+), \mathrm{M}(\mathrm{M} 0$ versus $\mathrm{M} 1)$, and staging (0-II versus IIIA-IV).

\section{RESULTS}

According to the Laurén's classification, 50 (66.7\%) of the tumors were intestinal type and $25(33.3 \%)$ of the tumors were diffuse. Vascular, lymph node and perineural infiltration were verified in $16 \%, 80 \%$ and $68 \%$ of the patients, respectively. Analysis of depth of the wall infiltration (pT) revealed T1 in $4(5.3 \%), \mathrm{T} 2$ in $27(36 \%)$ and $\mathrm{T} 3$ in $44(58.7 \%)$ of the tumors. Lymph node involvement ( $\mathrm{pN}+$ ) was detected in $72 \%$ of the cases and the presence of distant metastasis in $6.7 \%$. The patients were distributed according to the TNM staging in IA in $4(5.3 \%)$, IB in $10(13.3 \%)$, II in $15(20 \%)$, IIA in 15 $(20 \%)$, IIIB in $15(20 \%)$ and IV in $16(21.3 \%)$.

Regarding immunohistochemistry, Table 1 presents the distribution of the results regarding intensity and distribution for $\mathrm{p} 53$, cyclin D1 and Bcl-2. Table 2 shows the results of 
the univariate analysis between the protein $\mathrm{p} 53$ and cyclin D1, and clinicopathological characteristics of the patients. Bcl-2 immunoexpression was positive in all tumors, so it was excluded of the analysis. There was no association between the tumoral markers and the analyzed clinicopathological parameters. Figures 1 to 3 revealed imunohistochemical staining for $\mathrm{p} 53$, cyclin $\mathrm{D}$, and $\mathrm{Bcl}-2$, respectively.

TABLE 1. Distribution of the immunostaining results according to the intensity and distribution for $\mathrm{p} 53$, cyclin $\mathrm{D} 1$ and $\mathrm{Bcl}-2$

\begin{tabular}{lccccc}
\hline $\mathrm{p} 53$ & $\%$ & cyclin D1 & $\%$ & Bcl-2 & $\%$ \\
\hline 0 & 32,0 & 0 & 81,3 & 0 & 0 \\
+ & 0 & + & 0 & + & 0 \\
++ & 8,0 & ++ & 2,7 & ++ & 2,7 \\
+++ & 33,3 & +++ & 13,3 & +++ & 42,7 \\
+++ & 26,7 & ++++ & 2,7 & ++++ & 54,7 \\
\hline
\end{tabular}

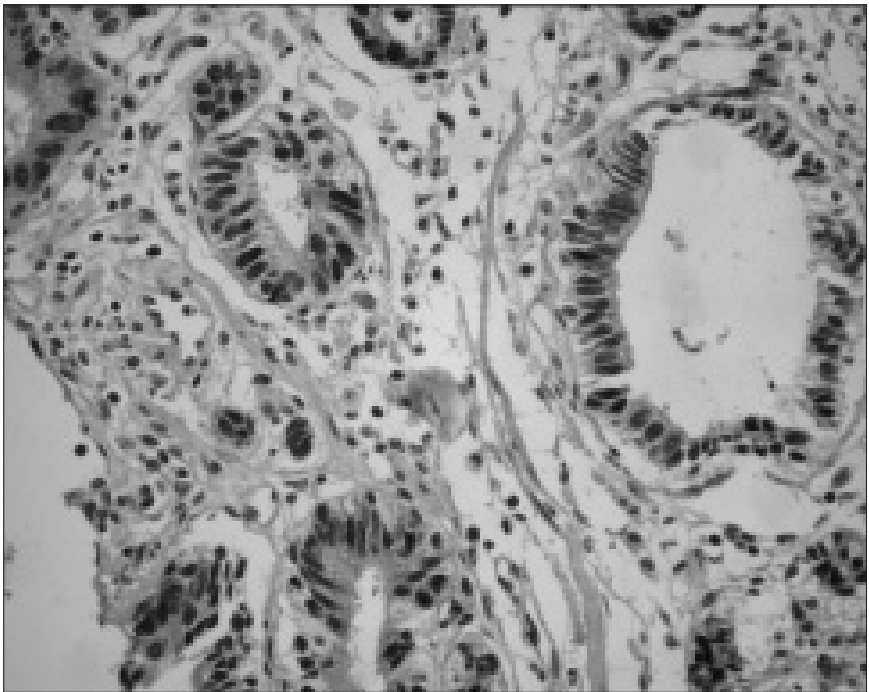

FIGURE 1. Imunohistochemical staining for p53 (200 x)

TABLE 2. Univariate analysis between p53 and cyclin D1 immunoexpressions and clinicopathological characteristics of the patients

\begin{tabular}{|c|c|c|c|c|c|c|}
\hline \multirow{3}{*}{$\bar{T}$ factor } & \multicolumn{3}{|c|}{$\mathrm{p} 53$} & \multicolumn{3}{|c|}{ cyclin D1 } \\
\hline & $+(\%)$ & $-(\%)$ & $P$ & $+(\%)$ & $-(\%)$ & $P$ \\
\hline & \multicolumn{6}{|c|}{$\mathrm{T}$ factor } \\
\hline T1 & $2(50.0)$ & $2(50.0)$ & $0.114^{a}$ & $1(25.0)$ & $3(75.0)$ & $0.707^{\mathrm{a}}$ \\
\hline $\mathrm{T} 2$ & $16(59.3)$ & $11(40.7)$ & & $4(14.8)$ & $23(85.2)$ & \\
\hline T3 & $33(75.0)$ & $11(25.0)$ & & $9(20,5)$ & $35(79.5)$ & \\
\hline \multicolumn{7}{|c|}{ Lymph node metastasis } \\
\hline No & $13(61.9)$ & $8(38.1)$ & $0.845^{b}$ & $5(23.8)$ & $16(76.2)$ & $0.342^{\mathrm{b}}$ \\
\hline N1 & $38(70.4)$ & $16(29.6)$ & & $9(16.7)$ & $45(83.3)$ & \\
\hline \multicolumn{7}{|l|}{ Distant metastasis } \\
\hline M0 & $47(67.1)$ & $23(32.9)$ & $0.484^{b}$ & $14(20.0)$ & $56(80.0)$ & $0.345^{b}$ \\
\hline M1 & $4(80.0)$ & $1(20.0)$ & & 0 & $5(100.0)$ & \\
\hline \multicolumn{7}{|l|}{ TNM Staging } \\
\hline IA & $2(50.0)$ & $2(50.0)$ & $0.199^{\mathrm{a}}$ & $1(25.0)$ & $3(75.0)$ & $0.529^{\mathrm{a}}$ \\
\hline IB & $6(60.0)$ & $4(40.0)$ & & $1(10.0)$ & $9(90.0)$ & \\
\hline II & $10(66.7)$ & $5(33.3)$ & & $5(33.3)$ & $10(66.7)$ & \\
\hline IIIA & $9(60.0)$ & $6(40.0)$ & & $1(6.7)$ & $14(93.3)$ & \\
\hline IIIB & $12(80.0)$ & $3(20.0)$ & & $5(33.3)$ & $10(66.7)$ & \\
\hline IV & $12(75.0)$ & $4(25.0)$ & & $1(6.3)$ & $15(93.8)$ & \\
\hline \multicolumn{7}{|l|}{ Vascular infiltration } \\
\hline Absent & $42(66.7)$ & $21(33.3)$ & $0.421^{\mathrm{b}}$ & $13(20.6)$ & $50(79.4)$ & $0.291^{\mathrm{b}}$ \\
\hline Present & $9(75.0)$ & $3(25.0)$ & & $1(8.3)$ & $11(91.7)$ & \\
\hline \multicolumn{7}{|c|}{ Lymph node infiltration } \\
\hline Absent & $7(46.7)$ & $8(53.3)$ & $0.065^{b}$ & $3(20.0)$ & $12(80.0)$ & $0.569^{b}$ \\
\hline Present & $44(73.3)$ & $16(26.7)$ & & $11(18.3)$ & $49(81.7)$ & \\
\hline \multicolumn{7}{|l|}{ Perineural invasion } \\
\hline Absent & $14(58.3)$ & $10(41.7)$ & $0.290^{\mathrm{b}}$ & $3(12.5)$ & $11(21.6)$ & $0.273^{b}$ \\
\hline Present & $37(72.5)$ & $14(27.5)$ & & $21(87.5)$ & $40(78.4)$ & \\
\hline \multicolumn{7}{|c|}{ Nakamura's classification } \\
\hline Intestinal & $9(64.3)$ & $5(35.7)$ & $0.564^{c}$ & 0 & $14(100.0)$ & $0.063^{\circ}$ \\
\hline Gastric & $33(66.0)$ & $17(34.0)$ & & $10(20.0)$ & $40(80.0)$ & \\
\hline Undifferentiated & $9(81.8)$ & $2(18.2)$ & & $4(36.4)$ & $7(63.66)$ & \\
\hline \multicolumn{7}{|l|}{ Laurén’s classification } \\
\hline Intestinal & $35(70.0)$ & $15(30.0)$ & $0.610^{c}$ & $8(16.0)$ & $42(84.0)$ & $0.531^{\mathrm{c}}$ \\
\hline Difuse & $16(64.0)$ & $9(36.0)$ & & $6(24.0)$ & $19(76.0)$ & \\
\hline
\end{tabular}




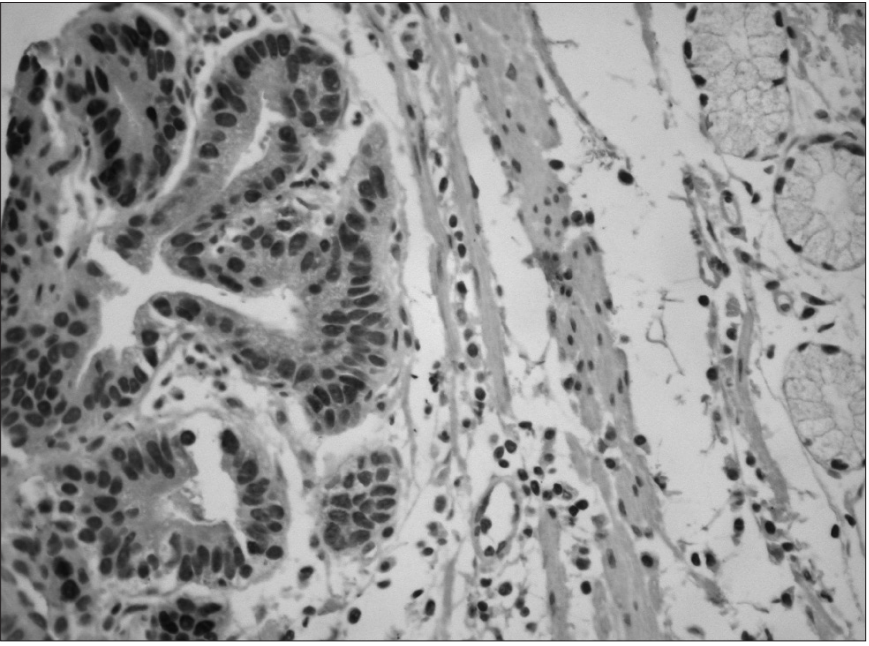

FIGURE 2. Imunohistochemical staining for cyclin D (200 x)

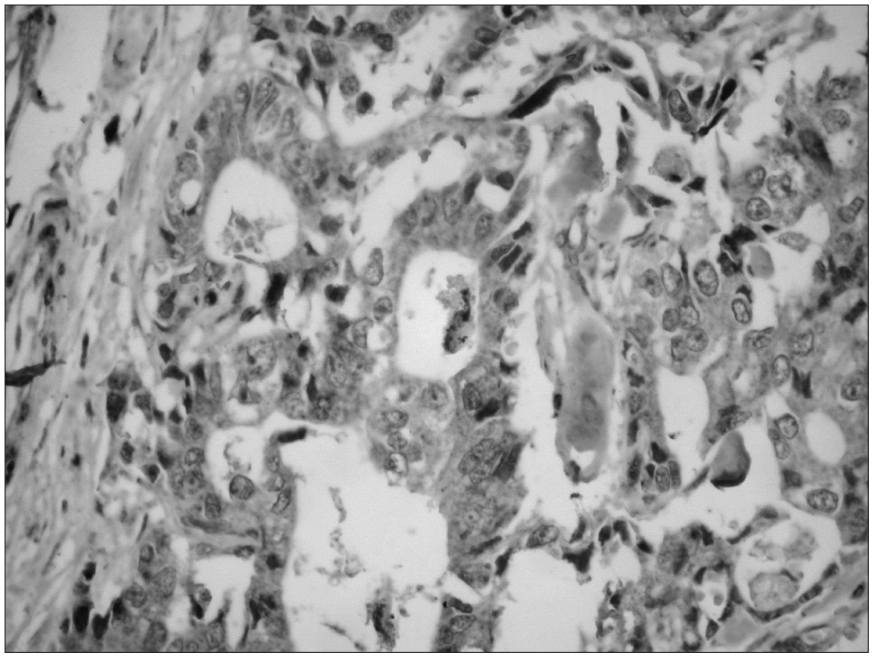

FIGURE 3. Imunohistochemical staining for Bcl-2 (200 x)

Of the 75 patients selected for this study, 6 were lost of follow-up, remaining for survival analysis a total of 69 patients. The mean follow-up time was 60 months, $\mathrm{SD}=$ 61.5 (varying from 4 to 273 months). All of the deaths were related to the neoplasia. There was no association between the immunomarkers and overall survival (Figures 4 and 5).

\section{DISCUSSION}

The association between modified genetic expressions with clinicopathological parameters may contribute for the clarification of isolated factors, which in addition to other findings of similar evaluations, integrates a knowledge armamentarium that may select patients for adequate treatment. In this study, we aimed to evaluate the immunoexpression of $\mathrm{p} 53$, cyclin D1 and Bcl-2 in samples of EGJ adenocarcinoma, without associated Barrett's esophagus, thus, eliminating the

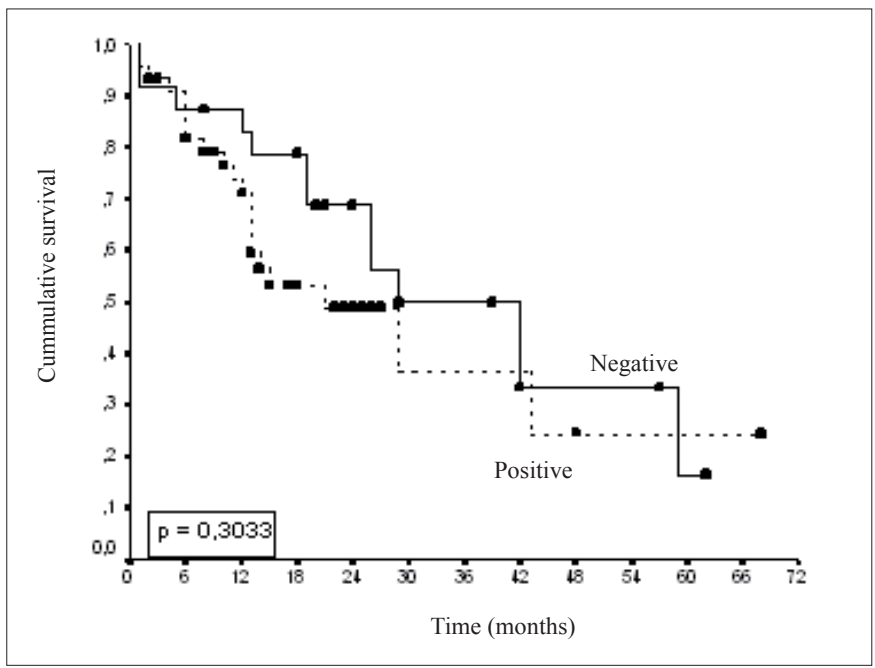

FIGURE 4. Cumulative curve of overall survival in 69 patients with EGJ adenocarcinoma according to $\mathrm{p} 53$ immunoexpression

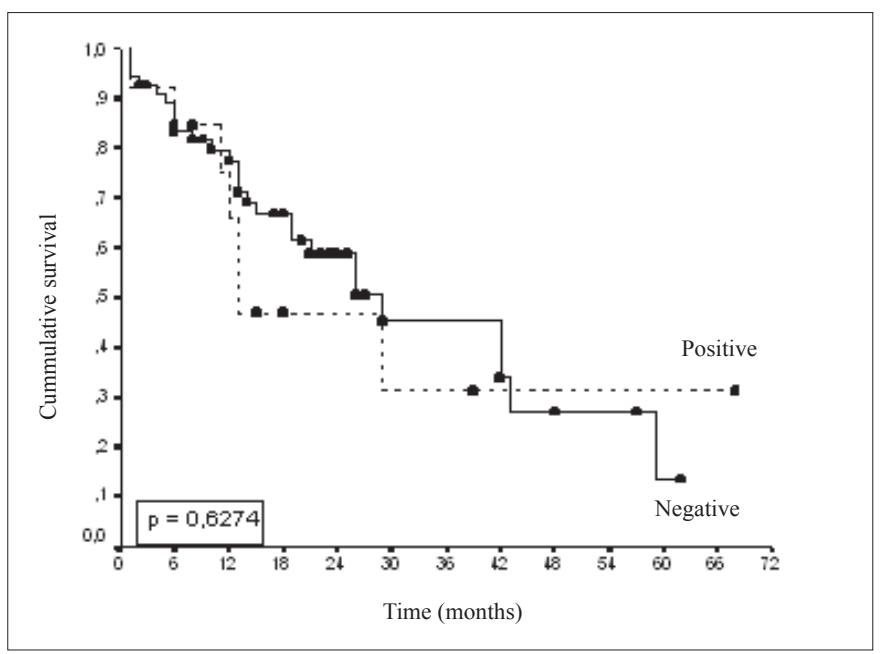

FIGURE 5. Cumulative curve of overall survival in 69 patients with EGJ adenocarcinoma according to Cyclin D1 immunoexpression

interference of possible factors related to the adenocarcinoma of esophagus. Marker immunoexpression had not been significantly associated with the clinicopathological data in this selected patient population.

Few studies had evaluated the immunoexpression of the mentioned markers in the EGJ adenocarcinoma (type II tumors), excluding cases with Barrett's esophagus, which may indicate type I tumors. In this study, three proteins were selected, whose modified expressions may correlate with different staging of development of EGJ adenocarcinomas, without Barrett's esophagus; $\mathrm{p} 53$, a tumor suppressor gene, cyclin $\mathrm{D} 1$, a cell cycle regulator and $\mathrm{Bcl}-2$, an oncogene that regulates apoptosis.

p53 immunoexpression is dependent on its accumulation in the cellular nucleus. p53 positive nuclear reactivity was 
detected in $68 \%$ in this study, and is in accordance with the literature results ${ }^{(13,14,21)}$. In normal situations, the protein $\mathrm{p} 53$ is immediately degraded in the nucleus by MDM2 protein action, after to exert its function. When there is a mutation involving the p53 gene, the quaternary structure of the p53 protein is modified, possibly by changing the positions of MDM2's recognition epitopes, avoiding the degradation process and causing an accumulation of protein p53 in the nucleus of the cell. However, immunohistochemical analysis is not $100 \%$ concordant with p 53 mutation, since other factors can contribute for the accumulation of this protein in the cellular nucleus, including the reduced activity of MDM2 protein. The results of the p53 immunoexpression in this investigation did not associate with the postoperative survival $(P=0,303)$ and, also did not present any association with the clinicopathological parameters by univariate analysis. These findings are in accordance with other published $\operatorname{data}^{(5,6,7,17,18,21,23,25,31,36,39)}$

IRELAND et al. ${ }^{(17)}$ verified p53 mutations in $48.6 \%$ of the studied adenocarcinomas, being $53 \%$ of esophagus and $58 \%$ of the cardia. In contrast, the presence of mutation was only detected in $17 \%$ of the subcardia adenocarcinomas. GONDA et al. ${ }^{(13)}$ also observed greater immunopositivity for p53 in the EGJ adenocarcinomas when compared with those located in the distal portion of the stomach, fact already previously registered by FLEJOU et al. ${ }^{(10)}$. In gastric carcinoma, GAO et al. ${ }^{(1)}$ had suggested that the positive expression of cyclin D1 can be an early event in the pathogenesis of this cancer and tends to remain steady during its progression until lymph node involvement and distant metastases occurred ${ }^{(32,41,42)}$. In 2005, IZZO et al. ${ }^{(19)}$ suggested that the evaluation of the expression of cyclin D1 in adenocarcinoma of the esophagus can be useful to evaluate the risk of progression of the illness. The increased cyclin D1 nuclear immunoexpression has been observed in $22 \%$ to $64 \%$ of esophageal adenocarcinoma, already being present in Barrett's metaplasia, and may be a marker of predictive value for malignancy $(1,2,12,20,24,30,38,44,45)$.

In this study the EGJ adenocarcinoma had increased cyclin D1 nuclear expression in $18.7 \%$ of the patients. Cyclin D1 immunoexpression was observed in $48 \%$ of the patients in early stage, in $47.6 \%$ of those in advanced stage, and $50 \%$ of those with distant metastases. Cyclin D1 immunoexpression was not associated to the clinicopathological characteristics, staging or survival, and was positive in all levels of invasion.

Bcl-2 immunoexpression was positive in all studied cases, so it was not possible to evaluate associations with any clinical or pathological parameters. In advanced esophageal squamous cell carcinoma, it was described the relationship of low expression of $\mathrm{Bcl}-2$ with overexpression of $\mathrm{p} 53$, suggesting an interaction of these two proteins in the progression of the illness ${ }^{(33)}$. In 1999, RIOUX-LECLERCQ et al. ${ }^{(37)}$ had shown that the Bcl-2 immunoexpression increased, along with mutations in the p53 gene, can be identified as primary events during the neoplastic progression in Barrett's esophagus. Recently, it was associated a significant reduction in the expression of bcl-2 to the progression of the mucosa of Barrett to esophageal adenocarcinoma $^{(35)}$.

\section{CONCLUSIONS}

Immunoexpression of $\mathrm{p} 53$ and cyclin D1 in patients with EGJ adenocarcinoma without associated Barrett's esophagus were regularly distributed in terms of intensity and distribution. Bcl-2 was detected in all cases. In this selected population, there was no association between the immunomarkers, $\mathrm{p} 53$, cyclin D1 and bcl-2 and clinicopathological data, staging and/or overall survival.

Lehrbach DM, Cecconello I, Ribeiro Jr U, Capelozzi VL, Ab'Saber AM, Alves VAF. Adenocarcinoma da junção esôfago-gástrica: relação entre os dados cllnipatológicos e a imunoexpressão de p53, ciclina D1 e Bcl-2. Arq Gastroenterol. 2009;46(4):315-20.

RESUMO - Contexto - O adenocarcinoma da junção esôfago-gástrica tem um comportamento agressivo e o estádio TNM não é sempre suficiente para categorizar o paciente de acordo com a evolução do mesmo. Objetivo - Avaliar a imunoexpressão do p53, ciclina D1 e Bcl-2 em pacientes com adenocarcinoma da junção esôfago-gástrica sem esôfago de Barrett e comparar com as características clínicas e sobrevida. Métodos - Cortes histológicos de 75 adenocarcinomas da esôfago-gástrica ressecados de 1991 a 2003 foram analisados por imunoistoquímica para o p53, ciclina D1 e Bcl-2, usando-se o método da estreptavidina-biotina-peroxidase. O tempo médio de seguimento foi de 60 meses, DP=61,5 (variando de 4 a 273 meses). Resultados - Cinquenta $(66,7 \%)$ dos tumores eram do tipo intestinal e $25(33,3 \%)$ eram difusos. Verificou-se infiltração vascular, linfonodal e perineural em $16 \%, 80 \%$ e $68 \%$ dos pacientes, respectivamente. O estádio TNM foi IA em 4 (5,3\%), II em 15 (20\%), IIIA em 15 (20\%), IIIB em 15 (20\%) e IV em $16(21,3 \%)$. A análise imunoistoquímica foi positiva para p53, ciclina D1 e Bcl-2 em 68\%, 18,7\% e 100, respectivamente. Não houve associação entre a imunoexpressão e invasão vascular ou perineural, características clinicopatológicas e sobrevida geral. Conclusão - Nesta população selecionada, não houve associação entre os imunomarcadores, p53, ciclina D1 e Bcl-2 e os dados clinicopatológicos e a sobrevida geral dos pacientes.

DESCRITORES - Junção esôfago-gástrica. Neoplasias gástricas. Neoplasias esofágicas. Adenocarcinoma. Proteína supressora de tumor p53. Ciclina D1. Proteínas proto-oncogênicas c-bcl-2. 


\section{REFERENCES}

1. Arber N, Lightdale C, Rotterdam H, Han KH, Sgambato A, Yap E, Ahsan H, Finegold J, Stevens PD, Green PH, Hibshoosh H, Neugut AI, Holt PR, Weinstein IB. Increased expression of the cyclin D1 gene in Barrett's esophagus. Cancer Epidemiol Biomarkers Prev. 1996;5:457-9.

2. Arber N, Gammon MD, Hibshoosh H, Britton JA, Zhang Y, Schonberg JB, Roterdam H, Fabian I, Holt PR, Weinstein IB. Overexpression of cyclin D1 occurs in both squamous carcinomas and adenocarcinomas of the esophagus and in adenocarcinomas of the stomach. Hum Pathol. 1999;30:1087-92.

3. Blot WJ, Devesa SS, Kneller RW, Fraumeni JF Jr. Rising incidence of adenocarcinoma of the esophagus and gastric cardia. JAMA. 1991;265:1287-9.

4. Bosch A, Fias Z, Caldwell W. Adenocarcinoma of the esophagus. Cancer. 1979;43:1557-61.

5. Casson AG, Tammemagi M, Eskandarian S, Redston M, McLaughlin J, Ozcelik H. p53 alterations in oesophageal cancer: association with clinico-pathological features, risk factors and survival. Mol Pathol. 1998;51:71-9.

6. Chang MS, Lee HS, Lee BL, Kim YT, Lee JS, Kim WH. Differential protein expression between esophageal squamous cell carcinoma and dysplasia, and prognostic significance of protein markers. Pathol Res Pract. 2005;201:417-25.

7. Chino O, Kijima H, Shimada H, Nishi T, Tanaka H, Kise Y, Kenmochi T, Himeno S, Machimura T, Tanaka M, Inokuchi S, Tajuma T, Osamura RY, Makuuchi H. Accumulation of $\mathrm{p} 53$ in esophageal squamous cell carcinoma. Int J Mol Med. 2001;8:359-63.

8. el-Deiry WS, Tokino T, Velculescu VE, Levy DB, Parsons R, Trent JM, Lin D, Mercer WE, Kinzler KW, Vogelstein B. WAF1, a potential mediator of p53 tumor supression. Cell 1993;75:817-25.

9. el-Deiry WS, Harper JW, O'Connor PM, Velculescu VE, Canman CE, Jackman J, Pietenpol JA, Burrell M, Hill DE, Wang Y, et al. WAF1/CIP1 is induced in p53-mediated G1 arrest and apoptosis. Cancer Res. 1994;54:1169-74.

10. Flejou JF, Gratio V, Muzeau F, Hamelin R. p53 abnormalities in adenocarcinoma of the gastric cardia and antrum. Mol Pathol. 1999;52:263-8.

11. Gao P, Zhou G, Liu Y, Li J, Zhen J, Yuan Y. Alteration of cyclin D1 in gastric carcinoma and its clinicopathologic significance. World J Gastroenterol. 2004;10:2936-9.

12. Geddert H, Kiel S, Zotz RB, Zhang J, Willers R, Gabbert HE, Sarbia M. Polymorphism of p16 (INK4A) and cyclin D1 in adenocarcinomas of the upper gastrointestinal tract. J Cancer Res Clin Oncol. 2005;15:1-6.

13. Gonda G, Bajtai A, Nagy P, Szanto I, Kiss J. Quantitative analysis of p53 expression and cell proliferation in gastric carcinomas. An immunohistochemical study. Hepatogastroenterology. 2004;51:273-6

14. Heeren PA, Kloppenberg FW, Hollema H, Mulder NH, Nap RE, Plukker JT. Predictive effect of $\mathrm{p} 53$ and $\mathrm{p} 21$ alteration on chemotherapy response and survival in locally advanced adenocarcinoma of the esophagus. Anticancer Res. 2004;24:2579-83.

15. Hesketh PJ, Clapp RW, Doos WG, Spechler SJ. The increasing frequency of adenocarcinoma of the esophagus. Cancer 1989;64:526-30.

16. Instituto Nacional do Câncer, Estimativa de Incidência de Câncer no Brasil para 2006.

17. Ireland AP, Shibata DK, Chandrasoma P, Lord RV, Peters JH, DeMeester TR Clinical significance of p53 mutations in adenocarcinoma of the esophagus and cardia. Ann Surg. 2000;231:179-87.

18. Itaya M, Yoshimoto J, Kojima K, Kawasaki S. Immunohistochemistry of p53, Bcl-2, and Ki-67 as predictors of chemosensitivity. Methods Mol Med. 2005;110:213-27.

19. Izzo JG, Malhotra U, Wu TT, Ensor J, Babenko IM, Swisher SG, Correa A, Bresalier RS, Hittelman WN, Ajani JA. Impact of cyclin D1 A870G polymorphism in esophageal adenocarcinoma tumorigenesis. Semin Oncol. 2005;32(6 Suppl 9):s11-s5.

20. Jenkins GJ, Doak SH, Parry JM, D’Souza FR, Griffiths AP, Baxter JN. Genetic pathways involved in the progression of Barrett's metaplasia to adenocarcinoma. Br J Surg. 2002;89:824-37.

21. Jovanovic I, Todorovic V, Milosavljevic T, Micev M, Pesko P, Bjelovic M, Mouzas Y, Tzardi M. Expression of p53 protein in Barrett's adenocarcinoma and adenocarcinoma of the gastric cardia and antrum. Vojnosanit Pregl. 2005;62:879-85.

22. Katada N, Hinder RA, Smyrk TC, Hirabayashi N, Perdikis G, Lund RJ, Woodward T, Klingler PJ. Apoptosis is inhibited early in the dysplasia-carcinoma sequence of Barrett's esophagus. Arch Surg. 1997;132:728-33.

23. Kurabayashi A, Furihata M, Matsumoto M, Ohtsuki Y, Sasaguri S, Ogoshi S Expression of Bax and apoptosis-related proteins in human esophageal squamous cell carcinoma including dysplasia. Mod Pathol. 2001;14:741-7.
24. Kuwahara M, Hirai T, Yoshida K, Yamashita Y, Hihara J, Inoue H, Toge T. p53, $\mathrm{p} 21$ (Waf1/Cip1) and cyclin D1 protein expression and prognosis in esophagea cancer. Dis Esophagus. 1999;12:116-9.

25. Lam KY, Law S, Tung PH, Wong J. Esophageal small cell carcinomas: clinicopathologic parameters, $\mathrm{p} 53$ overexpression, proliferation marker, and their impact on pathogenesis. Arch Pathol Lab Med. 2000;124:228-33.

26. Lane DP. Cancer. p53, guardian of the genome. Nature. 1992;358:15-6.

27. Lane DP. A death in the life of p53. Nature. 1993;362:786-7.

28. Lewin B. Genes VII. Oxford: Oxford University Press; 2000. p.858-9

29. Lukas J, Pagano M, Staskova Z, Draetta G, Bartek J. Cyclin D1 protein oscillates and is essential for cell cycle progression in human tumor cell lines. Oncogene. 1994;9:707-18.

30. Montesano R, Hainaut P. Molecular precursor lesions in oesophageal cancer. Cancer Surv. 1998;32:53-68.

31. Moskaluk CA, Heitmiller R, Zahurak M, Schwab D, Sidransky D, Hamilton SR. p53 and p21(WAF1/CIP1/SDI) gene products in Barrett esophagus and adenocarcinoma of the esophagus and esophagogastric junction. Hum Pathol. 1996;27:1211-20.

32. Nagasawa S, Masahiko O, Sasajima K, Makino H, Yamashita K, Takubo K, Miyashita M. Cyclin D1 overexpression as a prognostic factor in patients with esophageal carcinoma. J Surg Oncol. 2001;78:208-14

33. Parenti AR, Rugge M, Shiao YH, Ruol A, Ancona E, Bozzola L, Ninfo V. bcl-2 and p53 immunophenotypes in pre-invasive, early and advanced oesophageal squamous cancer. Histopathology. 1997;31:430-5.

34. Pezzella F, Tse AGD, Cordell JL, Pulford KAF, Gatter KC, Mason DY. Expression of the bcl-2 oncogene protein is not specific for the $14 ; 18$ chromosomal translocation. Am J Pathol. 1990;137:225-32.

35. Raouf AA, Evoy DA, Carton E, Mulligan E, Griffin MM, Reynolds JV. Loss of Bcl-2 expression in Barrett's dysplasia and adenocarcinoma is associated with tumor progression and worse survival but not with response to neoadjuvant chemoradiation. Dis Esophagus. 2003;16:17-23

36. Ribeiro U Jr, Finkelstein SD, Safatle-Ribeiro AV, Landreneau RJ, Clarke MR, Bakker A, Swalsky PA, Gooding WE, Posner MC. p53 sequence analysis predicts treatment response and outcome of patients with esophageal carcinoma. Cancer. 1998;83:7-18.

37. Rioux-Leclercq N, Turlin B, Sutherland F, Heresbach N, Launois B, Campion JP, Ramee MP. Analysis of Ki-67, p53 and Bcl-2 expression in the dysplasiacarcinoma sequence of Barrett's esophagus. Oncol Rep. 1999;6:877-82.

38. Roncalli M, Bosari S, Marchetti A, Buttitta F, Bossi P, Graziani D, Peracchia A, Bonavina L, Viale G, Coggi G. Cell cycle-related gene abnormalities and product expression in esophageal carcinoma. Lab Invest. 1998;78:1049-57.

39. Safatle-Ribeiro AV, Ribeiro U Jr, Sakai P, Clarke MR, Fylyk SN, Ishioka S, Gama-Rodrigues J, Finkelstein SD, Reynolds JC. Integrated p53 histopathologic/ genetic analysis of premalignant lesions of the esophagus. Cancer Detect Prev. 2000;24:13-23

40. Sannino P, Shousha S. Demonstration of oestrogen receptors in paraffin wax sections of breast carcinoma using the monoclonal antibody 1D5 and microwave oven processing. J Clin Pathol. 1994;47:90-2.

41. Sarbia M, Stahl M, Fink U, Heep H, Dutkowski P, Willers R, Seeber S, Gabbert HE. Prognostic significance of cyclin D1 in esophageal squamous cell carcinoma patients treated with surgery alone or combined therapy modalities. Int J Cancer. 1999;84:86-91.

42. Shinozaki H, Ozawa S, Ando N, Tsuruta H, Terada M, Ueda M, Kitajima M. Cyclin D1 amplification as a new predictive classification for squamous cell carcinoma of the esophagus, adding gene information. Clin Cancer Res. 1996;2:1155-61.

43. Sobin LH, Wittekind C, editors. TNM classification of malignant tumors. 6th edition. New York: Wiley-Liss; 2002. p.52-6.

44. Wang LD, Shi ST, Zhou Q, Goldstein S, Hong JY, Shao P, Qiu SL, Yang CS Changes in p53 and cyclin D1 protein levels and cell proliferation in different stages of human esophageal and gastric-cardia carcinogenesis. Int $\mathbf{J}$ Cancer. 1994;59:514-9

45. Weiss MM, Kuipers EJ, Hermsen MA, van Grieken NC, Offerhaus J, Baak JP, Meuwissen SG, Meijer GA. Barrett's adenocarcinomas resemble adenocarcinomas of the gastric cardia in terms of chromosomal copy number changes, but relate to squamous cell carcinomas of the distal oesophagus with respect to the presence of high-level amplifications. J Pathol. 2003;199:157-65.

Recebido em 26/12/2007.

Reapresentado em 18/5/2009.

Aprovado em 20/5/2009. 